\title{
Lack of circadian change of concentration of C-type natriuretic peptide in rabbit aqueous humor
}

\author{
Ausência de mudança no ritmo circadianoda concentraçãode peptídeo natriurético \\ tipo C no humor aquoso de coelhos
}

\author{
AugustoParanhos Jr. ${ }^{1}$ \\ Koji Okada ${ }^{2}$ \\ Paulo Augusto de Arruda Mello ${ }^{3}$ \\ João Antônio Prata Jr. ${ }^{4}$ \\ Doug'las Greg'ory ${ }^{5}$
}

\begin{tabular}{l} 
ABSTRACT \\
\hline Purpose: To determine whether there is a circadian change of the concen- \\
tration of C-type natriuretic peptide (CNP) in rabbit aqueous humor. \\
Methods: Forty-one male white New Zealand rabbits were submitted to a \\
$12 \mathrm{~h}$ light and 12 dark lighting schedule; lights on was at $0 \mathrm{~h}$, lights off at \\
$12 \mathrm{~h}$. C-type natriuretic peptide was assayed at 3 light $(2 \mathrm{~h}, 6 \mathrm{~h}$ and $10 \mathrm{~h})$ \\
and 3 dark $(14,18$ and $22 \mathrm{~h})$ times. All groups consisted of four animals but \\
two had more animals to increase the power of tests $(6 \mathrm{~h}, \mathrm{n}=12 ; 22 \mathrm{~h}, \mathrm{n}=13)$. \\
Dependence between the two eyes was tested by Pearson's correlation. \\
The mean of two eyes was considered for analysis. Differences in concen- \\
tration in pg/200 ml were evaluated by one-way ANOVA, $t$ test and \\
COSINOR analysis. Results: There were no significant differences between \\
the 6 analyzed groups (one-way ANOVA p=0.157). Pooled into two groups \\
(light and dark), the C-type natriuretic peptide concentration of the light \\
group was lower, $2.626 \pm 0.92$ pg/200 ml compared with the dark group \\
$3.02 \pm 1.16$ pg/200 ml but did not reach a significant difference $(t$ test; \\
p=0.23). COSINOR analysis was not statistically significant ( $\mathrm{R} \%=7.72$ \\
p=0.209). Conclusion: These data demonstrate that the concentration of \\
CNP in aqueous humor did not show a statistically significant circadian \\
change in rabbits entrained to a $12 \mathrm{~h}$ light: $12 \mathrm{~h}$ dark lighting schedule.
\end{tabular}

Keywords: Natriuretic agents; Cyclic GMP; Aqueous humor; Intraocular pressure; Ocular physiology/drug effects; Glaucoma; Natriuretic peptide, C-type; Circadian rhythm; Rabbits

\section{INTRODUCTION}

Type A, B and C natriuretic peptides (ANP, BNP, CNP) have been identified in aqueous humor ${ }^{(1-2)}$ and there is evidence that all can influence intraocular pressure (IOP) ${ }^{(1-5)}$. Fernandez-Durango et al. showed that all three are produced in the eye and their concentrations are not dependent on the systemic plasma concentration ${ }^{(6)}$. The concentration, receptor affinity and hypotensive effects of the 3 peptides differ. Stimulation of two of the natriuretic peptide receptors in the eye (NPRA and NPRB) increases cyclic GMP (which enhances aqueous humor outflow facility); the third, NPRC, functions as a clearance receptor ${ }^{(6)}$. ANP, BNP and CNP increase cGMP; CNP was the most potent. NPRB was the most important functionally ${ }^{(7)}$. NPRC occurs at a higher density in the trabecular meshwork and ciliary body ${ }^{(8-9)}$.

Rowland at al. described a model for the circadian rhythm of intraocular pressure (IOP) in New Zealand White rabbits; maximum IOP was during the dark and minimum during the light phase ${ }^{(10)}$. This was confirmed by Gregory et al., who also showed that superior cervical ganglionectomy decreased IOP in 
the dark and therefore that sympathetic tone is important at night $^{(11)}$. Aqueous humor production, like the rhythm of IOP, is greater during the dark ${ }^{(12)}$.

The propose of this study was to determine whether there is a circadian change of CNP in rabbit aqueous humor as a first step toward determining its relation to the circadian rhythms of IOP and aqueous humor production.

\section{METHODS}

All experimental procedures employing animals adhered to the ARVO Resolution on the Use of Animals in Research. Forty-one male New Zealand White rabbits weighing 2-3 kg were trained to a $12 \mathrm{~h}$ light: $12 \mathrm{~h}$ dark lighting schedule. Lights on was at $0 \mathrm{~h}$ and lights off at $12 \mathrm{~h}$.

Animals were sacrificed as described elsewhere (12) every 4 hours (light phase: 2 h, 6 h, $10 \mathrm{~h}$ and dark phase: 14 h, 18 h, 22 h). Temporal paracentesis was performed in both eyes with a $28 \mathrm{~g}$ needle and aqueous humor was collected, added to $0.5 \mathrm{ml}$ polypropylene microtubes containing anti-protease solutions ( $1 \mu \mathrm{l} 2 \mathrm{mM}$ EDTA, $1 \mu \mathrm{l} 2 \mathrm{mM}$ PMSF and $5 \mu \mathrm{l}$ 0,2 mM pepstatin A) and immediately frozen and stored at $-84^{\circ} \mathrm{C}$. CNP was measured by radioimmunoassay using kits from Peninsula Laboratories, INC, Belmont, CA-USA.

Correlation between the two eyes was tested by Pearson's correlation. The mean of two eyes was considered for analysis. Differences in concentration in $\mathrm{pg} / 200 \mathrm{ml}$ were evaluated by one-way ANOVA, t test and COSINOR analysis (COSINA 3.1, 1996 by Ana Amélia Benedito Silva). Differences were considered significant if $\mathrm{p}<0.05$.

\section{RESULTS}

There was a significant correlation of CNP concentration between the two eyes $(r=0.46, p=0.00223)$ so we used a mean of the two for analysis. There were no statistical differences among the six tested periods $(\mathrm{F}=1.72 ; \mathrm{p}=0.157)$. When the data were combined into two groups, (1) light (mean of $2 \mathrm{~h}, 6 \mathrm{~h}, 10 \mathrm{~h}$ ) and (2) dark (mean of $14 \mathrm{~h}, 18 \mathrm{~h}, 22 \mathrm{~h}$ ), the concentration of CNP appeared less in the light than in the dark $(2.626 \pm 0.917$ compared with $3.02 \pm 1.16$ picograms $/ 200$ milliliters). However, the two groups were not statistically significantly different $(\mathrm{p}=0.23)$ (Table 1$)$.
The COSINOR analysis showed no circadian rhythmus during 24 h analysis: mesor: -0.13 ; gamma $=0.44$; beta $=0.55$; amplitude $=0.47 ;$ acro $=2.51 ; \mathrm{R} \%=7.72 \mathrm{p}=0.209$.

\section{DISCUSSION}

This study failed to demonstrate a statistically significant daily change of the concentration of CNP in rabbit aqueous humor. Nevertheless, there is strong evidence that natriuretic peptides, especially CNP (2), can modulate intraocular pressure $^{(2-5,13-16)}$. Fernandez-Durango et al. reported that the effect of CNP on intraocular pressure reduction was 9-fold and 20fold higher than the effect of BNP and ANP, respectively ${ }^{(2)}$. CNP reduces IOP by increasing outflow facility and does not affect aqueous humor flow or uveoscleral outflow when injected intravitreally ${ }^{(3)}$. All natriuretic peptides can increase ocular cGMP concentrations but CNP was the most potent ${ }^{(2,17)}$. cGMP can decrease $\mathrm{Ca}^{+2}$ by stimulating cGMP-dependent protein kinase ${ }^{(17)}$ increasing $\mathrm{Na}^{+} / \mathrm{Ca}^{+2}$ exchange ${ }^{(18)}$ or increasing $\mathrm{Ca}^{+2}$ sequestration from the sarcolemma by activating the $\mathrm{Ca}^{+2}$ bomb or both ${ }^{(19)}$. Although the mechanism it is not known, these are possible ways that natriuretic peptides can act as "relaxants" of trabecular meshwork ${ }^{(7)}$.

The lack of substantial variation of the CNP concentration does not reflect a continuous amount of production. Because aqueous flow changes during the 24-hour light-dark cycle ${ }^{(12)}$ CNP production would also have to change in order for its aqueous concentration to remain constant.

The function of CNP in normal regulation of IOP is still not clear. Studies in pathological situations such as glaucoma are very important to better understand the roles of these peptides in the eye and could lead to new pharmacological therapies.

\section{RESUMO}

Objetivo: Verificar se há mudança na concentração circadiana de peptídeo natriurético tipo $\mathrm{C}(\mathrm{CNP})$ no humor aquoso de coelhos. Métodos: Quarenta e um coelhos machos da raça New Zealand foram admitidos numa rotina de 12 horas de luz e 12 de escuridão; luzes eram acesas na hora zero e apagadas na hora 12. O peptídeo natriurético tipo $\mathrm{C}$ era medido em três períodos com luz acesa (2, 6 e 10 h) e 3 com luz apagada (14, 18

\begin{tabular}{|c|c|c|c|c|c|c|c|}
\hline Time & Light & Mean & SD & Minimum & Maximum & $\mathbf{n}$ & p \\
\hline $2: 00$ & On & 2.40 & 0.66 & 1.50 & 3.10 & 4 & \\
\hline $6: 00$ & On & 2.84 & 1.03 & 1.71 & 5.10 & 12 & \\
\hline $14: 00$ & Off & 2.20 & 0.58 & 1.50 & 2.90 & 4 & \\
\hline $18: 00$ & Off & 2.55 & 0.72 & 2.00 & 3.60 & 4 & \\
\hline $22: 00$ & Off & 3.42 & 1.24 & 1.76 & 6.52 & 13 & 0.157 \\
\hline From $14: 00$ to $22: 00$ & Off & 3.02 & 1.16 & 1.50 & 6.52 & 21 & 0.230 \\
\hline
\end{tabular}


e $22 \mathrm{~h}$ ). Todos os grupos tinham 4 animais com exceção de dois períodos em que o $\mathrm{n}$ foi incrementado para aumentar o poder dos testes $(6 \mathrm{~h}, \mathrm{n}=12 ; 22 \mathrm{~h}, \mathrm{n}=13)$. A dependência entre os olhos foi testada por meio da correlação de Pearson. A média dos dois olhos foi usada para a análise. Diferença quanto à concentração média de peptídeo natriurético tipo $\mathrm{C}$ em $\mathrm{pg} / 200 \mathrm{ml}$ foi avaliada por meio do teste de one-way ANOVA, teste $t$ e análise de COSINOR. Resultados: Não foi encontrada diferença estatisticamente significante entre os 6 grupos analisados (one-way ANOVA; $\mathrm{p}=0,157$ ). Reunidos em dois grupos (luz e escuridão), a concentração de peptídeo natriurético tipo $C$ com a luz acesa foi mais baixa $(2,626 \pm 0,92 \mathrm{pg} / 200 \mathrm{ml})$ quando comparada ao grupo com luz apagada $(3,02 \pm 1,16 \mathrm{pg} /$ $200 \mathrm{ml}$ ) porém sem alcançar significância estatística (teste de t $\mathrm{p}=0,23)$. Análise de COSINOR não foi estatisticamente significante ( $\mathrm{R} \%=7,72 \mathrm{p}=0,209)$. Conclusão: Nossos dados demonstraram que a concentração do CNP no humor aquoso de coelhos não mostrou variação circadiana estatisticamente significante quando analisadas num ritmo de luz/escuro 12/12 h.

Descritores: Natriuréticos; GMP cíclico; Humor aquoso; Pressão intra-ocular; Fisiologia ocular/efeito de drogas; Glaucoma; Peptídeo natriurético tipo C; Ritmo circadiano; Coelhos

\section{REFERENCES}

1. Coca-Prados M, Escribano J, Ortego J. Differential gene expression in the human ciliary epithelium. Prog Retin Eye Res. 1999;18(3):403-29.

2. Fernandez-Durango R, Moya FJ, Ripodas A, De Juan JÁ, Fernandez-Cruz A, Bernal R. Type B and type C natriuretic peptide receptors modulate intraocular pressure in the rabbit eye. Eur J Pharmacol. 1999;364(2-3):107-13.

3. Takashima Y, Taniguchi T, Yoshida M, Haque MS, Igaki T, Itoh H, et al. Ocular hypotension induced by intravitreally injected C-type natriuretic peptide. Exp Eye Res. 1998;66(1):89-96.
4. Takashima Y, Taniguchi T, Yoshida M, Haque MS, Yoshimura N, Honda Y. Ocular hypotensive mechanism of intravitreally injected brain natriuretic peptide in rabbit. Invest Ophthalmol Vis Sci. 1996;37(13):2671-7.

5. Palm DE, Shue SG, Keil LC, Balaban CD, Severs WB. Effects of angiotensin, vasopressin and atrial natriuretic peptide on intraocular pressure in anesthetized rats. Neuropeptides. 1995;29(4):193-203.

6. Fernandez-Durango R, Nunez DJ, Brown MJ. Messenger RNAs encoding the natriuretic peptides and their receptors are expressed in the eye. Exp Eye Res. 1995;61(6):723-9.

7. Pang IH, Shade DL, Matsumoto S, SteelY HT, Desantis L. Presence of functional type B natriuretic peptide receptor in human ocular cells. Invest Ophthalmol Vis Sci. 1996;37(9):1724-31

8. Chang AT, Polansky JR, Crook RB. Natriuretic peptide receptors on human trabecular meshwork cells. Curr Eye Res. 1996;15(2):137-43.

9. Moya FJ, De Juan JA, Ripodas A, Bernal R, Fernandez-Cruz A, FernandezDurango R. Higher proportions of type C than of types A and B natriuretic peptide receptors exist in the rat ciliary body. Vision Res. 1998;38(24):3833-41.

10. Rowland JM, Potter DE, Reiter RJ. Circadian rhythm in intraocular pressure a rabbit model. Curr Eye Res. 1981;1(3):169-73.

11. Gregory DS, Aviado DG, Sears ML. Cervical ganglionectomy alters the circadian rhythm of intraocular pressure in New Zealand White rabbits. Curr Eye Res. 1985;4(12):1273-9.

12. Smith SD, Gregory DS. A circadian rhythm of aqueous flow underlies the circadian rhythm of IOP in NZW rabbits. Invest Ophthalmol Vis Sci. 1989; 30(4):775-8.

13. Wolfensberger TJ, Singer DR, Freegard T, Markandu ND, Buckley MG, MacGregor GA. Evidence for a new role of natriuretic peptides: control of intraocular pressure. Br J Ophthalmol. 1994;78(6):446-8.

14. Korenfeld MS, Becker B. Atrial natriuretic peptides. Effects on intraocular pressure, cGMP, and aqueous flow. Invest Ophthalmol Vis Sci. 1989;30(11) 2385-92.

15. Tsukahara S, Sasaki T, Yamabayashi S, Furuta M, Ushiyama M, Yamamoto T. Effect of alpha-human atrial natriuretic peptides on intraocular pressure in normal albino rabbits. Ophthalmologica. 1988;197(2):104-9.

16. Mittag TW, Tormay A, Ortega M, Severin C. Atrial natriuretic peptide (ANP), guanylate cyclase, and intraocular pressure in the rabbit eye. Curr Eye Res. 1987;6(10):1189-96.

17. Hassid A. Atriopeptin II decreases cytosolic free $\mathrm{Ca}$ in cultured vascular smooth muscle cells. Am J Physiol. 1986;251(5 Pt 1):C681-6.

18. Furukawa K, Ohshima N, Tawada-Iwata Y, Shigekawa M. Cyclic GMP stimulates $\mathrm{Na}+\mathrm{Ca} 2+$ exchange in vascular smooth muscle cells in primary culture. J Biol Chem. 1991;266(19):12337-41.

19. Popescu LM, Panoiu C, Hinescu M, Nutu O. The mechanism of cGMP-induced relaxation in vascular smooth muscle. Eur J Pharmacol. 1985;107(3):393-4. 